\title{
Tytuł profesora w Polsce w latach 1920-1990. Część 2. Warunki nadawania tytułu profesora w prawie o stopniach i tytułach naukowych
}

\section{Wprowadzenie}

W niecałe siedem lat od wejścia w życie Ustawy z dnia 5 listopada 1958 r. o szkołach wyższych ${ }^{1}$ po raz pierwszy nadawanie tytułów (stopni) naukowych poddano odrębnej regulacji. Uzasadnienia dla oddzielenia spraw kształcenia od spraw dotyczących kadry kształcącej i naukowej można dopatrywać się, po pierwsze, w dalszych przeobrażeniach ustrojowo-politycznych państwa socjalistycznego i rosnących jego potrzebach, ukierunkowanych również na rozszerzanie potencjału wykwalifikowanej kadry naukowo-dydaktycznej w szkołach wyższych oraz kadry naukowej w instytutach naukowych funkcjonujących poza nimi, $\mathrm{w}$ tym w nowo tworzonych; po drugie, w potrzebie uporządkowania spraw awansów naukowych kadry profesorskiej w szkołach wyższych w następstwie odstąpienia od rozwiązań przyjętych na wzór radziecki ustawą z 1951 r. ${ }^{2}$, z którymi z końcem roku 1958 ustawodawcy przyszło się zmierzyć, co nie pozostawało bez wpływu na przyjęte rozwiązania. Wyłączenie spraw nadawania tytułów (również stopni) naukowych spod prawa szkół wyższych nie dotyczyło wyłącznie tych szkół’ Wyłączeniem

${ }^{1}$ Dz.U. Nr 68, poz. 336 ze zm.

${ }^{2}$ Ustawa z dnia 14 XII 1951 r. o szkolnictwie wyższym i o pracownikach nauki (Dz.U. $1952 \mathrm{Nr} 6$, poz. 38 ze zm.).

${ }^{3}$ Zob. art. 34 ust. 3 Ustawy z dnia 5 XI 1958 r. o szkołach wyższych, w brzmieniu nadanym Ustawą z dnia 31 III 1965 r. o zmianie ustawy o szkołach wyższych (Dz.U. Nr 14, poz. 98). 
objęto także placówki naukowe Polskiej Akademii Nauk ${ }^{4}$ (PAN) oraz instytuty naukowo-badawcze ${ }^{5}$.

Ustawa z dnia 31 marca 1965 r. o stopniach naukowych i tytułach naukowych ${ }^{6}$ wzorem rozwiązań poprzedzających jej wejście

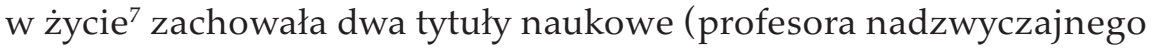
i profesora zwyczajnego), zarazem od wzorców tych odstąpiła, poza regulacją pozostawiając inne tytuły profesorskie. Prawne rozwiązania dotyczące dwóch tytułów naukowych w znacznym jednak stopniu zmieniła, bądź to upraszczając niektóre rozwiązania dotychczasowe lub zastępując rozwiązania dawne nowymi, bądź odstępując od niektórych z nich. I w tym znaczeniu ustawa z 1965 r. była ustawą nowatorską (na ówczesne warunki i czasy). Przepisy upraszczające dotychczasowe rozwiązania dotyczyły m.in. trybu i warunków zgłaszania kandydatów do tytułu profesora; z kolei to, co było bezwzględnie nowe, można sprowadzić do: (1) bliższego określenia dziedzin nauki lub dyscypliny naukowej (albo określonej dziedziny sztuki lub dyscypliny artystycznej), w których tytuły naukowe profesora mogły być nadawane, (2) warunków stawianych przed kandydatami do tytułów profesorskich oraz (3) przebiegu postępowania o nadanie tytułów profesora, a także (4) organów współuczestniczących w procesie prowadzącym do ich nadania.

Przyjęty ustawą z 1965 r. oraz wydanymi na jej podstawie przepisami wykonawczymi zakres regulacji bez wattpienia pozwala poszerzyć rozważania przyjęte w części pierwszej artykułu (poświęcone tytułom profesora w prawie szkół wyższych ${ }^{8}$ ) o spojrzenie i analizę rozwiązań nowych (przepisów odrębnych). Jednocześnie pozwala w pełni ukazać tę instytucję prawną w latach 1920-1990.

${ }^{4}$ Zob. art. 49 Ustawy z dnia 17 II 1960 r. o Polskiej Akademii Nauk (Dz.U. Nr 10, poz. 64), w brzmieniu nadanym Ustawą z dnia 31 III 1965 r. o zmianie ustawy o Polskiej Akademii Nauk (Dz.U. Nr 14, poz. 99).

${ }^{5}$ Zob. art. 30 Ustawy z dnia 17 II 1961 r. o instytutach naukowo-badawczych (Dz.U. Nr 12, poz. 60), w brzmieniu nadanym Ustawą z dnia 31 III 1965 r. o zmianie ustawy o instytutach naukowo-badawczych (Dz.U. Nr 14, poz. 100).

${ }^{6}$ Dz.U. Nr 14, poz. 101 ze zm.

${ }^{7}$ Ustawa z dnia 31 III 1965 r. weszła w życie z dniem 9 IV 1965 r.

${ }^{8}$ K. Wojtczak, Tytuł profesora w Polsce w latach 1920-1990. Czesść 1. Warunki przyznawania tytułu profesora w prawie szkół wyższych, "Studia Prawa Publicznego" 2017, nr 4(20), s. 55-94. 


\section{Tytuły naukowe profesora a dziedziny nauki (sztuki)}

Ustawa z 1965 r. stała wyraźnie na stanowisku, że tytułami naukowymi są tytuły profesora nadzwyczajnego i profesora zwyczajnego określonej dziedziny nauki lub dyscypliny naukowej albo dziedziny sztuki lub dyscypliny artystycznej (art. 16 ust. 1). Dla bliższego ich określenia (także określenia dziedzin nauki i dyscyplin naukowych przyjętych dla stopni naukowych) jednocześnie zobowiązała ministra szkolnictwa wyższego działającego w porozumieniu z sekretarzem naukowym Polskiej Akademii Nauk. I tę ustawową delegację minister wypełnił, wydając łącznie siedem zarządzeń, w tym cztery zarządzenia zmieniające, spośród których do tytułów profesora wprost odniesiono pięć (w tym dwa zarządzenia zmieniające). Pierwszym z zarządzeń, z dnia 15 lipca 1965 r. ${ }^{9}$, minister bliżej określił prawo nadawania tytułów profesora (nadzwyczajnego i zwyczajnego) w zakresie dwudziestu nauk (chemicznych, ekonomicznych, farmaceutycznych, fizycznych, humanistycznych, leśnych, matematycznych, medycznych, prawnych, przyrodniczych, rolniczych, technicznych, weterynaryjnych, wojskowych, wychowania fizycznego, plastycznych, filmowych, sztuki muzycznej, sztuki teatralnej, teologii). W roku $1970^{10}$ katalog dziedzin nauki rozszerzono o prawo nadawania tytułów profesora (nadzwyczajnego i zwyczajnego) w dziedzinach nauk: geograficznych oraz nauk politycznych. W dwa lata później minister nauki i szkolnictwa wyższego nowym zarządzeniem ${ }^{11}$ ustanowił dwadzieścia trzy dziedziny nauki, dopełniając wcześniej przyjęte rozwiązania o dziedzinę nauk towaroznawczych, by w roku $1974^{12}$ rozszerzyć je o dziedzinę nauk o organizacji i zarządzaniu. Do czasu wydania kolejnego zarządzenia tytuły naukowe profesora mo-

${ }^{9}$ Zarządzenie Ministra Szkolnictwa Wyższego z dnia 15 VII 1965 r. w sprawie bliższego określenia stopni naukowych i tytułów naukowych w zależności od dziedziny nauki lub dyscypliny naukowej, których te stopnie i tytuły dotyczą (M.P. Nr 38, poz. 218).

${ }^{10}$ Zarządzenie Ministra Oświaty i Szkolnictwa Wyższego z dnia 2 II 1970 r. zmieniające zarządzenie w sprawie bliższego określenia stopni naukowych i tytułów naukowych w zależności od dziedziny nauki lub dyscypliny naukowej, których te stopnie i tytuły dotyczą (M.P. Nr 5, poz. 44).

${ }^{11}$ Zarządzenie Ministra Nauki, Szkolnictwa Wyższego i Techniki z dnia 20 VIII 1972 r. w sprawie bliższego określenia stopni naukowych i tytułów naukowych w zależności od dziedziny nauki lub dyscypliny naukowej, których te stopnie i tytuły dotyczą (M.P. Nr 44, poz. 234).

12 Zarządzenie Ministra Nauki, Szkolnictwa Wyższego i Techniki z dnia 16 VII 1974 r. zmieniające zarządzenie w sprawie bliższego określenia stopni naukowych i tytułów 
gły być zatem nadawane w dwudziestu czterech dziedzinach nauki. Tymczasem rok $1986^{13}$ przyniósł nowe w tym zakresie rozwiązania. Dla bliższego określenia tytułów profesora powrócono do dwudziestu dziedzin nauki. I choć w podstawowym zakresie je zachowano, rezygnacją z nich objęto dziedziny nauk wprowadzonych od 1970 r., tj.: nauk geograficznych, nauk politycznych, nauk towaroznawczych oraz nauk o organizacji i zarządzaniu, równocześnie zastępując dziedzinę nauki wychowania fizycznego dziedziną - kultury fizycznej. I tego stanu prawnego nie zmieniono do czasu uchylenia zarządzenia z 1986 r., tj. do dnia 31 marca $1991 \mathrm{r}$.

\section{Warunki stawiane przed kandydatami do tytułów profesorskich}

W warunkach przestrzegania zasady, w zakresie jakich dziedzin nauki mogły być nadawane tytuły profesora, kandydatom do nich stawiano określone wymagania. Wbrew założeniom dotyczyły ich one jedynie pośrednio. Dziedziny nauki wyznaczały bowiem granice, do których wymagania stawiane przed kandydatami do tytułów profesora (nadzwyczajnego i zwyczajnego) mogły znaleźć odniesienie.

Sam zakres prawem określonych wymagań nie był wartością stałą. Zgodnie z ustawą z 1965 r. w jej brzmieniu pierwotnym tytuł profesora nadzwyczajnego mógł być nadany osobie posiadającej stopień naukowy docenta ${ }^{14}$ (od 1968 r. doktora habilitowanego ${ }^{15}$ ), która osiągnęła

naukowych w zależności od dziedziny nauki lub dyscypliny naukowej, których te stopnie i tytuły dotyczą (M.P. Nr 27, poz. 161).

${ }^{13}$ Zarządzenie Ministra Nauki i Szkolnictwa Wyższego z dnia 18 VI 1986 r. w sprawie dziedzin nauki i dyscyplin naukowych, w zakresie których mogą być nadawane stopnie naukowe, oraz bliższego określenia stopni naukowych i tytułów naukowych (M.P. Nr 18, poz. 125).

${ }^{14}$ Artykuł 17 ust. 1 Ustawy z dnia 31 III 1965 r. o stopniach naukowych i tytułach naukowych. Zob. też art. 11 ust. 2 tejże ustawy oraz Rozporządzenie Rady Ministrów z dnia 8 II 1966 r. w sprawie warunków i trybu przeprowadzania przewodów doktorskich i habilitacyjnych (Dz.U. Nr 8, poz. 53 ze zm.).

${ }^{15}$ Ustawa z dnia 20 XII 1968 r. o zmianie ustawy o stopniach naukowych i tytułach naukowych (Dz.U. Nr 46, poz. 335). Szerzej na temat przewodów habilitacyjnych i uzyskiwanych stopni naukowych zob.: K. Wojtczak, Habilitacje w Polsce Ludowej. Część 1. Warunki i przebieg habilitacji w prawie szkót wyższych, "Studia Prawa Publicznego” 2017, nr 1(17), s. 25-61; eadem, Habilitacje w Polsce Ludowej. Czesść 2. Warunki i przebieg habilitacji w prawie o stopniach i tytułach naukowych, "Studia Prawa Publicznego” 2017, nr 2(18), s. 43-81. 
poważne wyniki w pracy naukowej i w kształceniu kadr naukowych (od 1968 r. pomnożyła swój dorobek naukowo-badawczy i dydaktyczno-wychowawczy). Z kolei od kandydata do tytułu naukowego profesora zwyczajnego wymagano nie tylko posiadania tytułu profesora nadzwyczajnego, ale i uzyskania po jego osiągnięciu wydatnie powiększonego dorobku w pracy naukowej i w kształceniu kadr naukowych (od 1968 r. wydatnie pomnożonego dorobku naukowo-badawczego i dydaktyczno-wychowawczego). Jednocześnie ustawą zmieniającą z 1968 r. dookreślono pojęcie dorobku dydaktyczno-wychowawczego, którym objęto udział w zorganizowanym kształceniu i doskonaleniu kadr naukowych oraz kierowanie zespołami badawczymi ${ }^{16}$. Od $1985 \mathrm{r}$. awanse naukowe do tytułów profesora nadzwyczajnego i profesora zwyczajnego (przy zachowaniu dotychczasowych wymagań) wzmocniono o kryterium następne. Tytuł naukowy mógł być bowiem nadany osobie, która "w pełni akceptuje konstytucyjne zasady ustrojowe Polskiej Rzeczypospolitej Ludowej i kieruje się nimi w swojej działalności"17.

Od zasady posiadania wyższego stopnia naukowego lub tytułu naukowego przewidziano dwa wyjątki. Pierwszy pozwalał kandydatom do tytułu profesora niespełniającym tego warunku na odstąpienie od wykazania się dorobkiem w zakresie kształcenia kadr naukowych w razie ich zatrudnienia w instytucjach nieprowadzących takiego kształcenia

${ }^{16}$ Rozwiązanie to przyjęto także art. 25 ust. 3 Ustawy z dnia 12 IX 1990 r. o tytule naukowym i stopniach naukowych (Dz.U. Nr 65, poz. 386 ze zm.). Ustawa z dnia 14 III 2003 r. o stopniach naukowych i tytule naukowym (Dz.U. Nr 65, poz. 595 ze zm. w brzmieniu pierwotnym) od tego rozwiązania odstąpiła. Do unormowań przyjętych w latach 1968 i 1990 powrócono w 2011 r. mocą Ustawy z dnia 18 III 2011 r. o zmianie ustawy - Prawo o szkolnictwie wyższym, ustawy o stopniach naukowych i tytule naukowym oraz o stopniach i tytule w zakresie sztuki oraz o zmianie niektórych innych ustaw (Dz.U. Nr 84, poz. 455), przez przyjęcie jako przesłanki (rozłącznej) służącej ocenie osiągnięć naukowych i dydaktycznych kandydata do tytułu profesora - kierowanie zespołami badawczymi. To nietrafne oderwanie od oceny przesłanki szerszej - osiągnięć naukowych - słusznie krytycznej ocenie poddali H. Izdebski i J. Zieliński (Prawo o szkolnictwie wyższym. Ustawa o stopniach i tytule naukowym. Komentarz do nowelizacji, Warszawa 2011, s. 462-463). Wątpliwości powstałe na tle osiągnięć kandydata do tytułu profesora usunęła dopiero Ustawa z dnia 11 VII 2014 r. o zmianie ustawy - Prawo o szkolnictwie wyższym oraz niektórych innych ustaw (Dz.U. poz. 1198) i wydane na jej podstawie Rozporządzenie Ministra Nauki i Szkolnictwa Wyższego z dnia 3 X 2014 r. w sprawie szczegółowego trybu i warunków przeprowadzania czynności w przewodzie doktorskim, w postępowaniu habilitacyjnym oraz w postępowaniu o nadanie tytułu profesora (Dz.U. poz. 1383).

${ }^{17}$ Artykuł 1 pkt 14 Ustawy z dnia 25 VII 1985 r. o zmianie ustawy o stopniach naukowych i tytułach naukowych (Dz.U. Nr 36, poz. 168). 
(co można uznać za zasadne). Wyjątek drugi z kolei odnoszono także do osób, w przypadkach wyjątkowych, nieposiadających stopnia naukowego i tytułu naukowego ani stażu pracy na stanowisku pracownika naukowo-dydaktycznego lub naukowo-badawczego, mających poważne osiągnięcia w pracy naukowej lub w twórczej pracy zawodowej oraz kwalifikacje do prowadzenia pracy naukowej i kształcenia kadr naukowych w zakresie wymaganym od profesora (co dzisiaj budziłoby wątpliwości). To ostatnie kryterium ocenne od 1973 r. zastąpiono uwarunkowaniem nowym, a mianowicie tytuł profesora mógł być nadany (już bez odwołania do przypadków wyjątkowych) osobie nieposiadającej stopnia naukowego i tytułu naukowego mającej wybitne, zastosowane $\mathrm{w}$ praktyce osiągnięcia $\mathrm{w}$ pracy naukowo-badawczej lub w twórczej pracy zawodowej oraz kwalifikacje do prowadzenia pracy naukowo-dydaktycznej i dydaktyczno-wychowawczej w zakresie wymaganym od profesora ${ }^{18}$.

Nieco inaczej ustawodawca uregulował wymagania stawiane przed kandydatami do tytułów naukowych (profesora nadzwyczajnego lub profesora zwyczajnego) w dziedzinie sztuki i dyscyplin artystycznych. Szczególność przyjętych tu rozwiązań sprowadzała się, po pierwsze, do odstąpienia od wymogu posiadania przez kandydata do tytułu naukowego profesora stopnia naukowego docenta (od 1968 r. stopnia naukowego), po drugie, do oparcia oceny jego wyników w pracy naukowej (od 1968 r. w pracy naukowo-badawczej) i kształceniu kadr naukowych (tu bez kierowania zespołami badawczymi) również na odpowiednim uznaniu wyników pracy artystycznej, dorobku w pracy artystycznej oraz w kształceniu kadry naukowo-dydaktycznej ${ }^{19}$.

\section{Warunki i tryb postępowania w przedmiocie nadania tytułów profesora}

Postępowanie prowadzące do nadania tytułów profesora było wieloetapowe, podporządkowane dość stabilnym rozwiązaniom prawnym. Począwszy od 1965 r., na mocy ustawy o stopniach naukowych

${ }^{18}$ Artykuł 1 pkt 9 Ustawy z dnia 12 IV 1973 r. o zmianie przepisów dotyczących stopni naukowych i tytułów naukowych oraz organizacji instytutów naukowo-badawczych (Dz.U. Nr 12, poz. 89).

${ }^{19}$ Artykuł 17 ust. 5 Ustawy z dnia 31 III 1965 r. o stopniach naukowych i tytułach naukowych. 
i tytułach naukowych inicjowała je uchwała rady (wydziału, naukowej20) o wszczęciu postępowania w sprawie wysunięcia kandydata do tytułu naukowego, podjęta $\mathrm{z}$ własnej inicjatywy lub na podstawie wniosku złożonego: (1) w szkołach wyższych i w samodzielnych placówkach typu naukowo-dydaktycznego ${ }^{21}$ - przez dziekana wydziału lub kierownika innej jednostki organizacyjnej szkoły wyższej (od 1986 r. ${ }^{22}$ z wyłączeniem jednostek działających w ramach wydziałów) albo samodzielnej placówki naukowo-dydaktycznej, (2) w placówkach naukowych PAN kierownika placówki, a w instytutach naukowo-badawczych - dyrektora instytutu (od 1985 r. w jednostkach badawczo-rozwojowych ${ }^{23}$ - na wniosek dyrektora jednostki). W efekcie podjęcia stosownej uchwały właściwa rada była zobowiązana do: (1) wyboru składu komisji oraz (2) wyznaczenia recenzentów.

W kwestii pierwszej, mocą zarządzenia z $1965 \mathrm{r}^{24}$, właściwa rada wybierała z grona swych członków trzyosobową komisję (bez wskazania prawem stawianych im wymagań w zakresie kwalifikacji $\left.{ }^{25}\right)$. W latach

${ }^{20}$ Artykuł 34 ust. 3 Ustawy z dnia 5 XI 1958 r. o szkołach wyższych, w brzmieniu nadanym Ustawą z dnia 31 III 1965 r. o zmianie ustawy o szkołach wyższych; art. 18 Ustawy z dnia 31 III 1965 r. o wyższym szkolnictwie wojskowym (Dz.U. Nr 14, poz. 102). Zob. też art. 21 b ust. 3 Ustawy z dnia 31 III 1965 r. o wyższym szkolnictwie wojskowym, w brzmieniu nadanym Ustawą z dnia 16 VII 1987 r. o zmianie ustawy o wyższym szkolnictwie wojskowym (Dz.U. Nr 22, poz. 128). Od 1968 r. w stosunku do międzywydziałowych i pozawydziałowych jednostek organizacyjnych szkoły wyższej funkcje rady wydziału pełnił senat, jeżeli jednostki te nie miały własnych rad naukowych (art. 1 pkt 26 Ustawy z dnia 20 XII 1968 r. o zmianie ustawy o szkolnictwie wyższym (Dz.U. Nr 45, poz. 334).

${ }^{21}$ Było nią Centrum Medyczne Kształcenia Podyplomowego, utworzone Rozporządzeniem Rady Ministrów z dnia 9 X 1970 r. w sprawie utworzenia samodzielnej placówki naukowo-dydaktycznej pod nazwą Centrum Medyczne Kształcenia Podyplomowego (Dz.U. Nr 29, poz. 247).

22 Zarządzenie Ministra Nauki i Szkolnictwa Wyższego oraz Sekretarza Naukowego Polskiej Akademii Nauk z dnia 11 VIII 1986 r. w sprawie trybu składania przez rady wydziału i rady naukowe wniosków o przedstawienie kandydatów do tytułu naukowego (M.P. Nr 28, poz. 202).

${ }^{23}$ Ustawa z dnia 25 VII 1985 r. o jednostkach badawczo-rozwojowych (Dz.U. Nr 36, poz. 170). Zob. też art. 1 pkt 5 Ustawy z dnia 29 V 1989 r. zmieniającej ustawę o stopniach naukowych i tytułach naukowych (Dz.U. Nr 34, poz. 183).

${ }^{24}$ Zarządzenie Ministra Szkolnictwa Wyższego i Sekretarza Naukowego Polskiej Akademii Nauk z dnia 13 XII 1965 r. w sprawie trybu składania przez rady wydziału i rady naukowe wniosków o przedstawienie kandydatów do tytułu naukowego (M.P. $1966 \mathrm{Nr}$ 1, poz. 11).

${ }^{25}$ Na mocy Ustawy z dnia 5 XI 1958 r. o szkołach wyższych skład rady wydziału tworzyli dziekan i prodziekani, a ponadto samodzielni pracownicy nauki danego wydziału, jeden przedstawiciel wykładowców oraz corocznie wybierani dwaj przedstawiciele 
następnych wprawdzie powołanie trzyosobowej komisji zachowano, dopiero jednak od roku 1986 (również w drodze zarządzenia ${ }^{26}$ ) bliżej określono jej skład. Odtąd komisję mogły tworzyć osoby wybrane spośród członków danej rady mające tytuł profesora, ale także osoby zajmujące stanowisko docenta i mające stopień naukowy doktora habilitowanego (co nie pozostawało bez znaczenia dla wyróżnionej ówcześnie hierarchii stanowisk ${ }^{27}$ ).

Zakres działania komisji podlegał pewnym zmianom. Początkowo ich zadaniem było ustalenie wykazu osób, do których należało zwrócić się o opinię o kandydacie, i opierając się na nich, a także na ocenach recenzentów - sporządzenie ogólnego sprawozdania. Wykaz miał obejmować wszystkie „osoby posiadające tytuł naukowy profesora

pomocniczych pracowników nauki (od 1965 r. profesorowie i docenci, kierownicy naukowych i dydaktycznych jednostek organizacyjnych wydziału oraz w łącznej liczbie od dwóch do ośmiu przedstawiciele grup pracowników naukowo-dydaktycznych wydziału: wykładowców, adiunktów, starszych asystentów i asystentów; od 1968 r. również przedstawiciel uczelnianej organizacji Polskiej Zjednoczonej Partii Robotniczej, przewodniczący wydziałowej rady do spraw młodzieży; od 1982 r. pozostali profesorowie, docenci i doktorzy habilitowani zatrudnieni na wydziale oraz przedstawiciele: innych nauczycieli akademickich wybrani w sposób określony przez senat szkoły, przedstawiciele studentów wydziału oraz zatrudnionych w wydziale pracowników szkoły niebędących nauczycielami akademickimi; od 1985 r. pozostali profesorowie i docenci zatrudnieni na wydziale oraz przedstawiciel studium wojskowego, a także dwaj przedstawiciele pozostałych nauczycieli akademickich, po jednym przedstawicielu delegowanym przez: organy partii, stronnictw politycznych oraz związku zawodowego, wydziałowych organów organizacji studenckich i młodzieżowych o zasięgu ogólnokrajowym - działających na wydziale, oraz przewodniczący wydziałowego organu samorządu studenckiego). Zob. art. 36 Ustawy z dnia 5 XI 1958 r. o szkołach wyższych; art. 1 pkt 25 Ustawy z dnia 31 III 1965 r. o zmianie ustawy o szkołach wyższych; art. 1 pkt 28 Ustawy z dnia 20 XII 1968 r. o zmianie ustawy o szkolnictwie wyższym; art. 44 ust. 1 Ustawy z dnia 4 V 1982 r. o szkolnictwie wyższym (Dz.U. Nr 14, poz. 113); art. 1 pkt 24 Ustawy z dnia 25 VII 1985 r. o zmianie ustawy o szkolnictwie wyższym (Dz.U. Nr 36, poz. 167).

${ }^{26}$ Paragraf 3 zarządzenia Ministra Nauki i Szkolnictwa Wyższego oraz Sekretarza Naukowego Polskiej Akademii Nauk z dnia 11 VIII 1986 r. w sprawie trybu składania przez rady wydziału i rady naukowe wniosków o przedstawienie kandydatów do tytułu naukowego.

${ }^{27}$ Zgodnie z art. 46 ustawy o stopniach naukowych i tytule naukowym, w brzmieniu nadanym Ustawą z dnia 20 XII 1968 r. o zmianie ustawy o szkolnictwie wyższym na stanowisko docenta mogła być powołana osoba mająca co najmniej stopień naukowy doktora w zakresie danej lub pokrewnej dziedziny nauki oraz odpowiedni dorobek naukowy lub zawodowy osiągnięty po uzyskaniu tego stopnia i która wykazała się przygotowaniem do prowadzenia samodzielnej pracy naukowej, dydaktycznej i wychowawczej. Stopień naukowy doktora habilitowanego świadczył natomiast o posiadaniu dorobku naukowego wymaganego do zajęcia stanowiska docenta. 
nadzwyczajnego lub profesora zwyczajnego tej samej specjalności, a w ich braku - specjalności pokrewnej, lub wybitnych specjalistów w danej dziedzinie, chociażby nie posiadali tytułu naukowego profesora". Dla dziekana lub przewodniczącego rady naukowej wykaz ten stanowił jedynie podstawę podjęcia dalszych działań: zwrócenia się do osób objętych wykazem o wyrażenie w ciągu jednego miesiąca opinii wraz z uzasadnieniem, czy kandydat do tytułu profesora odpowiada wymaganiom stawianym przez ustawę. Tym samym zadanie tej komisji zbliżono do rozwiązań obowiązujących w poprzednich latach, z tą jednak różnica, że zapytanie o opinię o kandydacie zindywidualizowano. Dotyczyć mogło jedynie kandydata w nim wyraźnie wskazanego, po powzięciu przez właściwą radę uchwały o wszczęciu postępowania w sprawie wysunięcia tej kandydatury do tytułu profesora.

Od zasięgania opinii o kandydacie do tytułu profesora odstąpiono dość wcześnie, bo w 1969 r. ${ }^{28}$ Wprawdzie wyłanianie przez właściwa radę (wydziału, naukową) trzyosobowej komisji zachowano, jednak od tego roku jej zadanie sprowadzono do zapoznania się z ocenami recenzentów powołanych przez właściwą radę i na tej wyłącznie podstawie sporządzenia ogólnego sprawozdania. Rozwiązanie to było niezwykle trafne, znacznie upraszczające wszczęcie postępowania w sprawie wysunięcia kandydata do tytułu naukowego, abstrahując tu od trudności w jego realizacji ze względu na sukcesywnie poszerzaną liczbę szkół wyższych, placówek naukowych PAN i instytutów naukowych ${ }^{29}$ oraz

${ }^{28}$ Zarządzenie Ministra Oświaty i Szkolnictwa Wyższego i Sekretarza Naukowego Polskiej Akademii Nauk z dnia 17 IV 1969 r. zmieniające zarządzenie w sprawie trybu składania przez rady wydziału i rady naukowe wniosków o przedstawienie kandydatów do tytułu profesora (M.P. Nr 20, poz. 169).

${ }^{29}$ Począwszy od 1965 r., stopniowo tworzono kolejne szkoły wyższe, placówki PAN, instytuty naukowe. Nie zamierzając wymienić ich wszystkich, przykładowo można wskazać na te utworzone w latach 1965-1990: (1) w grupie szkół wyższych - Uniwersytet Śląski w Katowicach (Rozporządzenie Rady Ministrów z dnia 18 VI 1968 r. w sprawie utworzenia Uniwersytetu Śląskiego w Katowicach - Dz.U. Nr 18, poz. 116); Uniwersytet Gdański (Rozporządzenie Rady Ministrów z dnia 20 III 1970 r. w sprawie utworzenia Uniwersytetu Gdańskiego - Dz.U. Nr 6, poz. 49); Uniwersytet Szczeciński (Ustawa z dnia 21 VII 1984 r. o utworzeniu Uniwersytetu Szczecińskiego - Dz.U. Nr 36, poz. 190 oraz Rozporządzenie Rady Ministrów z dnia 31 VII 1985 r. w sprawie rozpoczęcia działalności Uniwersytetu Szczecińskiego - Dz.U. Nr 36, poz. 172); Akademia Medyczna w Bydgoszczy (Ustawa z dnia 21 VII 1984 r. o utworzeniu Akademii Medycznej w Bydgoszczy - Dz.U. Nr 35, poz. 191); (2) w grupie placówek naukowych PAN m.in.: Instytut Automatyki (od 10 II 1972 r.), Instytut Cybernetyki Stosowanej (od 14 I 1975 r.), Instytut Badań Lekarskich, Instytut Chemii Fizycznej, Instytut Nauk Prawnych; (3) w grupie instytutów naukowo-badawczych m.in. Instytut Badania Prawa 
uzyskiwanych tytułów profesora, w konsekwencji także na tok prowadzonego w tym przedmiocie postępowania.

W kwestii drugiej, dotyczącej wyznaczenia recenzentów, częstotliwość zmian ówcześnie przyjętych rozwiązań nie była większa. W istocie rozwiązania sprowadzono do dwóch przesłanek: (1) liczby powoływanych recenzentów oraz (2) wyznaczonej im roli w ocenie kandydata do tytułu profesora. Ustawa z 1965 r. nie wypowiadała się co do liczby recenzentów. Obowiązek wyznaczenia przez właściwą radę (wydziału, naukową), w drodze uchwały, dwóch recenzentów wprowadzono zarządzeniem z dnia 13 grudnia 1965 r. Mocą zarządzenia zmieniającego z 1969 r. liczbę tę zwiększono do trzech. I tego stanu rzeczy nie zmieniono do czasu wejścia w życie rozwiązań wprowadzonych na mocy ustawy z roku 1990. To, co w tym okresie podlegało zmianom, dotyczyło natomiast wskazania, spośród jakich osób właściwa rada mogła recenzentów wyznaczyć. Zarządzenie pierwsze (z 1965 r.) stanowiło tylko tyle, że recenzentem mógł być profesor zwyczajny albo profesor nadzwyczajny. Kolejne zarządzenie (z 1969 r.) wprawdzie od tego postanowienia nie odstąiło, nim już jednak wymagano dochowania warunku nowego, właściwą radę obligując do wyznaczenia dwóch (z trzech) recenzentów spoza instytucji zatrudniającej kandydata. $Z$ kolei zarządzeniem trzecim (z 1986 r.) ustanowiono szerszą regułę postępowania w tym zakresie. Otóż recenzentem mogła być osoba posiadająca tytuł naukowy przy założeniu, że co najmniej dwóch z recenzentów miało być powołanych spoza grona pracowników i emerytowanych pracowników szkoły wyższej, placówki naukowej PAN, samodzielnej jednostki typu naukowo-dydaktycznego, jednostki badawczo-rozwojowej, w której wszczęto postępowanie w sprawie wysunięcia kandydata do tytułu naukowego, oraz spoza grona członków rady. Po raz pierwszy wyraźnie również ustanowiono zakaz łączenia funkcji recenzenta z członkostwem komisji.

Stosownie do właściwości danej rady (wydziału, naukowej) o przedstawienie oceny do recenzentów zwracał się dziekan wydziału lub przewodniczący rady naukowej. Oceny miały być sporządzone w ciągu trzech

Sądowego (Zarządzenie nr 73 Prezesa Rady Ministrów z dnia 28 IX 1973 r. w sprawie utworzenia Instytutu Badania Prawa Sądowego - M.P. Nr 43, poz. 256), Instytut Kultury (Zarządzenie nr 26 Prezesa Rady Ministrów z dnia 26 II 1974 r. w sprawie utworzenia Instytutu Kultury - M.P. Nr 9, poz. 67), Instytut Gospodarki Narodowej (Zarządzenie nr 54 Prezesa Rady Ministrów z dnia 30 XII 1981 r. w sprawie utworzenia Instytutu Gospodarki Narodowej - M.P. Nr 33, poz. 295), Instytut Gospodarki Materiałowej (Zarządzenie nr 11 Prezesa Rady Ministrów z dnia 20 IV 1982 r. w sprawie utworzenia Instytutu Gospodarki Materiałowej - M.P. Nr 11, poz. 80). 
miesięcy i miały być odpowiedzią na pytanie, czy oceniony przez recenzenta dorobek kandydata uzasadnia wystąienie z wnioskiem o nadanie mu tytułu naukowego. I choć cel sporządzenia oceny był jasno wyznaczony, zakres materii objęty tą oceną był określony różnie. Recenzentom powierzono bowiem ocenę: dorobku naukowego kandydata (1965), całego dorobku naukowo-badawczego (a w zakresie sztuki i dyscyplin artystycznych - dorobku w pracy artystycznej) i dydaktyczno-wychowawczego (1969), dorobku naukowo-badawczego ze szczególnym uwzględnieniem dorobku powstałego po ostatnim awansie naukowym (1986).

Złożenie opinii i ocen otwierało drogę do dalszych prac komisji, właściwej rady, dziekana, rektora i senatu (w szkołach wyższych), sekretarza naukowego PAN, kierownika placówki naukowej PAN, dyrektora instytutu (jednostki). W generalnej ocenie były to dyspozycje prawne jasno sformułowane, mimo że i one $\mathrm{w}$ badanym okresie podlegały pewnym zmianom.

Na mocy rozwiązań przyjętych w 1965 r. komisja, po otrzymaniu i zapoznaniu się z opiniami (kadry profesorskiej objętej wykazem) i ocenami (recenzentów), sporządzała ogólne sprawozdanie i przedstawiała je wraz ze swoim stanowiskiem i uzasadnieniem odpowiednio właściwej radzie: (1) wydziału (radzie naukowej innej jednostki organizacyjnej szkoły wyższej), (2) naukowej placówki PAN i instytutu - istniejących poza szkołami wyższymi. Opinie i oceny dotyczące kandydatów wymagały zachowania poufności. W szkołach wyższych dla rady wydziału (rady naukowej innej jednostki organizacyjnej) przedstawione jej materiały stanowiły podstawę do podjęcia w głosowaniu tajnym ${ }^{30}$ uchwały o wystapieniu lub o odmowie wystąpienia z wnioskiem o przedstawienie kandydata do tytułu naukowego. $\mathrm{W}$ razie podjęcia przez radę uchwały pozytywnej dla kandydata dziekan (kierownik innej jednostki) uchwałę tę (wraz z załącznikami ${ }^{31}$ ) przekazywał rektorowi, a ten senatowi uczelni do zatwierdzenia ${ }^{32}$. Zatwierdzoną przez senat uchwałę

\footnotetext{
${ }^{30}$ Podjęcie uchwały wymagało większości 2/3 głosów obecnych na posiedzeniu rady (wydziału, naukowej) osób wchodzących w skład rady i zajmujących stanowiska: profesorów zwyczajnych, profesorów nadzwyczajnych, docentów etatowych lub samodzielnych pracowników naukowo-badawczych, przy udziale co najmniej połowy ogólnej liczby członków rady uprawnionych do głosowania.

${ }^{31}$ Do uchwały rady należało dołączyć: wszystkie materiały, sprawozdania i opinie oraz protokół posiedzenia rady wydziału lub rady naukowej innej jednostki organizacyjnej szkoły wyższej obejmujący wyniki głosowania.

${ }^{32}$ Uchwała senatu w tym przedmiocie zapadała większością 2/3 głosów obecnych na posiedzeniu osób wchodzących w skład senatu, przy udziale co najmniej połowy
} 
rady wydziału (rady naukowej innej jednostki) rektor przekazywał, wraz z pełną dokumentacja, właściwemu ministrowi (sprawującemu nadzór nad szkołą wyższą). Natomiast w razie powzięcia pozytywnej w tym przedmiocie uchwały przez radę naukową placówki naukowej PAN, instytutu naukowo-badawczego lub samodzielnej placówki typu naukowo-dydaktycznego przekazywał ją (wraz z dokumentacją) sekretarzowi naukowemu PAN lub właściwemu ministrowi - kierownik danej placówki, dyrektor danego instytutu naukowo-badawczego lub kierownik samodzielnej placówki typu naukowo-dydaktycznego. Prawodawca milczeniem pominął natomiast skutki prawne powzięcia przez właściwą radę negatywnej dla kandydata uchwały. Tym samym opowiedział się za rozwiązaniem odstąpienia od nadawania tytułu profesora jako kolejnego awansu naukowego.

Rok 1969 nie przyniósł w tym zakresie zbyt wielu zmian, aczkolwiek te, które wprowadzono, miały wagę znaczącą. Dla podjęcia przez radę wydziału (radę naukową jednostki organizacyjnej) lub radę naukową placówek i instytutów istniejących poza szkołami wyższymi uchwały o wystąpieniu lub niewystąpieniu $\mathrm{z}$ wnioskiem o przedstawienie kandydata do tytułu naukowego profesora nadzwyczajnego lub profesora zwyczajnego wystarczyła większość ( w miejsce 2/3) głosów obecnych na posiedzeniu rady osób wchodzących w jej skład i zajmujących stanowiska: profesorów zwyczajnych, profesorów nadzwyczajnych, docentów (już nie etatowych) lub samodzielnych pracowników naukowo-badawczych, przy udziale co najmniej połowy ogólnej liczby członków rady uprawnionych do głosowania. Ponadto w szkołach wyższych odstąpiono od obowiązku zatwierdzania przez senat uchwały rady wydziału w sprawie wysunięcia kandydata do tytułu naukowego na rzecz innego rozwiązania, w warunkach ściśle określonych. Otóż rektor mógł (nie był więc już zobowiązany) przedstawić senatowi uchwałę rady wydziału (rady naukowej jednostki) w sprawie wysunięcia kandydata do tytułu naukowego w celu jej zaopiniowania, i to tylko wtedy, gdy wysunięcie kandydata do tytułu naukowego miało nastąpić $\mathrm{w}$ związku $\mathrm{z}$ zamierzonym powołaniem go na stanowisko profesora $w$ danej szkole wyższej. Z punktu widzenia zaangażowania senatu danej szkoły wyższej w rolę organu opiniującego $\mathrm{w}$ postępowaniu $\mathrm{w}$ sprawie wystąpienia $\mathrm{z}$ wnioskiem o nadanie kandydatowi tytułu naukowego wydaje się to zrozumiałe. Zważywszy jednak na to, że $\mathrm{z}$ wnioskiem o wszczęcie postępowania $\mathrm{w}$ tym przedmiocie

ogólnej liczby członków uprawnionych do głosowania (§ 7 ust. 2 w zw. z $§ 6$ ust. 2 zarządzenia z dnia 13 XII 1965 r.). 
mógł wystąpić jedynie dziekan lub kierownik jednostki organizacyjnej szkoły wyższej, a można tu zasadnie założyć brak zgodności oczekiwań dziekana i rektora tej samej szkoły wyższej w zakresie oceny potrzeby zatrudnienia kandydata do tytułu profesora, sytuacja osoby kandydującej do tego tytułu bez wątpienia była słaba. I to zarówno w latach objętych analiza, jak i w okresie później przyjętych rozwiązań ${ }^{33}$.

Kolejne zarządzenie, z 1986 r., nieco zmieniło wcześniejsze w tym zakresie uwarunkowania prawne. To, co dla prowadzonego postępowania było najistotniejsze, poza nowymi (wprowadzonymi zarządzeniem z 1969 r.) rozwiązaniami w zakresie wskazania podmiotów uprawnionych do przedstawiania kandydatów do tytułów naukowych profesora, wyznaczonej uchwałą rady (wydziału, naukowej) roli komisji i jej zadań oraz udziału w tym postępowaniu recenzentów, dotyczyło ponadto: (1) ustalenia członków rady uprawnionych do głosowania w sprawach nadawania tytułów naukowych (również w wyższych szkołach artystycznych), w tym tytułów naukowych w dziedzinie nauk wojskowych lub specjalistycznych dyscyplin naukowych o bezpieczeństwie państwa i porządku publicznym oraz ochronie przeciwpożarowej; (2) sentencji podejmowanych uchwał rady (wydziału, naukowej) w sprawie wystąpienia z wnioskiem o przedstawienie kandydata do tytułu naukowego profesora; (3) określenia obowiązku rektora w zakresie prowadzonego postępowania.

W kwestii pierwszej uprawnieniem do głosowania objęto: członków właściwej rady (wydziału, naukowej) mających tytuł naukowy lub tytuł docenta ze stopniem naukowym doktora habilitowanego, a w wyższych szkołach artystycznych również docentów niemających stopnia naukowego $^{34}$. W przypadku natomiast nadawania tytułów naukowych w dziedzinie nauk wojskowych bądź specjalistycznych dyscyplin naukowych osobom zatrudnionym w szkole wyższej uprawnieniami w tym zakresie objęto także członków rady wydziału będących oficerami w stopniu generała (admirała) ${ }^{35}$. W kwestii drugiej z kolei prawodawca odstąpił

${ }^{33}$ Po raz pierwszy prawodawca expressis verbis wszczęcie postępowania prowadzącego do nadania tytułu profesora na wniosek kandydata do tego tytułu zapewnił dopiero w 2015 r. Zob. Rozporządzenie Ministra Nauki i Szkolnictwa Wyższego z dnia 30 X 2015 r. w sprawie szczegółowego trybu i warunków przeprowadzania czynności w przewodzie doktorskim, w postępowaniu habilitacyjnym oraz w postępowaniu o nadanie tytułu profesora (Dz.U. poz. 1842).

${ }^{34}$ Paragraf 6 ust. 1 Zarządzenia Ministra Nauki i Szkolnictwa Wyższego oraz Sekretarza Naukowego Polskiej Akademii Nauk z dnia 11 VIII 1986 r.

${ }^{35}$ Paragraf 6 ust. 2 Zarządzenia Ministra Nauki i Szkolnictwa Wyższego oraz Sekretarza Naukowego Polskiej Akademii Nauk z dnia 11 VIII 1986 r. 
od podejmowania przez właściwą radę uchwały w sprawie niewystąpienia $z$ wnioskiem o nadanie kandydatowi tytułu naukowego, co nie pozostawało bez znaczenia, zważywszy, że ustawa nie przewidywała środków ochrony prawnej od negatywnej uchwały rady w tym przedmiocie. W kwestii trzeciej natomiast, po otrzymaniu uchwały właściwej rady rektora na powrót zobowiązano do przedstawienia senatowi opinii o kandydacie wyłącznie zatrudnionym w szkole wyższej.

\section{Organy uprawnione do przedstawienia wniosku o nadanie tytułu profesora nadzwyczajnego lub profesora zwyczajnego i nadania tych tytułów}

Ustawa z 1965 r. utorowała dwie ścieżki prowadzące do nadania tytułu naukowego (profesora nadzwyczajnego lub profesora zwyczajnego) i odpowiednio do nich wyznaczyła właściwość organów. Dla pierwszej z nich ustanowiła, umownie tu przyjmując, standardowe postępowanie, dla ścieżki drugiej natomiast założyła odstępstwa podyktowane uzasadnionymi przypadkami. Rozwiązanie trzecie wskazały przepisy przejściowe.

W sytuacji pierwszej podjęcie przez radę wydziału lub radę naukową uchwały w sprawie wystąpienia $\mathrm{z}$ wnioskiem o przedstawienie kandydata do tytułu naukowego profesora nadzwyczajnego lub profesora zwyczajnego, przy odpowiednim stosowaniu w szkołach wyższych przepisów odnoszonych do obowiązków rektora i senatu w tym zakresie, prowadziło do kolejnego etapu postępowania. Inicjowało je przekazanie wniosku (uchwały) rady wydziału (lub rady naukowej innej jednostki organizacyjnej szkoły wyższej), rady naukowej placówki naukowej PAN oraz rady naukowej instytutu naukowo-badawczego (badawczo-rozwojowego) w sprawie wysunięcia kandydata do tytułu naukowego profesora zatrudnionego $\mathbf{w}$ danej jednostce (wraz z pełną dokumentacją ${ }^{36}$ ) - odpowiednio: (1) ministrowi sprawującemu nadzór nad szkołą wyższą lub samodzielną jej placówką typu naukowo-dydaktycznego, (2) sekretarzowi naukowemu PAN w placówkach naukowych Akademii; (3) ministrowi, któremu dany instytut naukowo-badawczy podlegał, a w sytuacji niemieszczącej się w powyższym podziale (4) ministrowi

${ }^{36}$ Dokumentacją objęto: uchwałę senatu oraz wszystkie materiały, sprawozdania i oceny, a także protokoły z przebiegu każdego posiedzenia rady wydziału (rady naukowej) wraz z wynikami głosowania. 
szkolnictwa wyższego (od 1966 r. ministrowi oświaty i szkolnictwa wyższego, od 1972 r. ministrowi nauki, szkolnictwa wyższego i techniki, od 1985 r. ministrowi nauki i szkolnictwa wyższego, od 1987 r. ministrowi edukacji narodowej) działającemu w porozumieniu z sekretarzem naukowym PAN.

Właściwemu ministrowi oraz sekretarzowi naukowemu PAN przyjęcie wniosku w powyższym zakresie otwierało drogę do jego przedstawienia prezesowi Rady Ministrów. Ustawodawca zarazem zastrzegł, że przedstawienie szefowi rządu wniosku w tym przedmiocie wymagało uprzednio zasięgnięcia opinii odpowiednio: Rady Głównej Szkolnictwa Wyższego ${ }^{37}$ (w przypadku pierwszym i czwartym, od 1973 r. tylko w przypadku czwartym), Rady Wyższego Szkolnictwa Artystycznego ${ }^{38}$, Rady Wyższego Szkolnictwa Wojskowego (od 1987 r. Rady Wyższej Szkolnictwa Wojskowego i Nauki ${ }^{39}$ ) oraz Głównej Komisji Kwalifikacyjnej działającej przy PAN ${ }^{40}$ (w przypadku drugim i trzecim).

${ }^{37}$ Radę Główną Szkolnictwa Wyższego w strukturę szkolnictwa wyższego wprowadzono dość wcześnie. Dekretem z dnia 28 X 1947 r. o organizacji nauki i szkolnictwa wyższego (Dz.U. Nr 66, poz. 415 ze zm.) utworzono Radę Główną Szkolnictwa Wyższego do Spraw Nauki i Szkolnictwa Wyższego; na mocy Ustawy z dnia 15 XII 1951 r. o szkolnictwie wyższym i o pracownikach nauki radę tę nazwano Radą Główną Szkolnictwa Wyższego i w tym kształcie zachowano także Ustawą z dnia 5 XI 1958 r. o szkołach wyższych. Ustawa z dnia 31 III 1965 r. Radę tę zachowała jako organ doradczy i opiniodawczy ministra do 1973 r. (tekst jedn. Dz.U. Nr 32, poz. 192). Do niej już jako Rady Głównej Nauki i Szkolnictwa Wyższego powróciła Ustawa z dnia 4 V 1982 r. o szkolnictwie wyższym, zarazem przekazując tej Radzie kompetencje ministra nauki, szkolnictwa wyższego i techniki w odniesieniu do jednostek organizacyjnych szkół wyższych (zob. art. 2 ust. 3 ustawy z 1965 r. o stopniach naukowych i tytułach naukowych, w brzmieniu nadanym art. 214 Ustawy z dnia 4 V 1982 r. o szkolnictwie wyższym). Od 1985 r. zawężono jej zakres działania. Ostatnia kadencja Rady wygasła z dniem 31 XII 1990 r. (art. 183 ust. 3 Ustawy z dnia 12 IX 1990 r. o szkolnictwie wyższym (Dz.U. Nr 65, poz. 385). Ponadto działały: Rada Wyższa Szkolnictwa Artystycznego, Rada Wyższa Szkolnictwa Wojskowego, od 1982 r. także: Rada Wyższa Szkolnictwa Medycznego oraz Rada Wyższego Szkolnictwa Kultury Fizycznej (art. 16 ust. 2 Ustawy z dnia 4 V 1982 r. o szkolnictwie wyższym - Dz.U. Nr 14, poz. 113 ze zm.).

${ }^{38}$ Zgodnie z art. 4 Ustawy z dnia 29 III 1962 r. o wyższych szkołach artystycznych (Dz.U. Nr 20, poz. 88 ze zm.) do Rady Wyższego Szkolnictwa Artystycznego miały zastosowanie odpowiednio przepisy ustawy o szkołach wyższych dotyczące Rady Głównej Szkolnictwa Wyższego. Zob. też Uchwałę nr 130 Rady Ministrów z dnia 23 VII 1969 r. w sprawie regulaminu Rady Wyższego Szkolnictwa Artystycznego (M.P. Nr 34, poz. 249).

${ }^{39}$ Artykuł 5 Ustawy z dnia 31 III 1965 r. o wyższym szkolnictwie wojskowym (Dz.U. Nr 14, poz. 102 ze zm.), w brzmieniu nadanym art. 1 pkt 3 Ustawy z dnia 16 VII 1987 r. o zmianie ustawy o wyższym szkolnictwie wojskowych (Dz.U. Nr 22, poz. 128).

${ }^{40}$ Pierwotnie Komisja Kwalifikacyjna działająca przy PAN na mocy Ustawy z dnia 17 II 1960 r. o Polskiej Akademii Nauk (Dz.U. Nr 10, poz. 64 ze zm.), od 1965 r. - Główna 
Procedurę postępowania w tym zakresie nieco zmieniły rozwiązania z lat późniejszych. W roku 1973 przywrócono instytucję Centralnej Komisji Kwalifikacyjnej (już z dookreśleniem) do Spraw Kadr Naukowych $^{41}$, wprowadzoną w 1951 r., a odrzuconą ustawą z 1958 r. ${ }^{42}$ Odtąd przed przedstawieniem prezesowi Rady Ministrów kandydatów do tytułu naukowego należało zasięgnąć opinii tejże Komisji ${ }^{43}$ (w miejsce Rady Głównej Szkolnictwa Wyższego), przy zachowaniu prawa do opinii w sprawie przedstawienia kandydata do tytułu naukowego profesora dla: Rady Głównej Szkolnictwa Wojskowego (w zakresie nauk wojskowych) oraz Rady Wyższego Szkolnictwa Artystycznego (w zakresie dyscyplin artystycznych). W roku 1982 na mocy art. 232 pkt 2 ustawy z dnia 4 maja uchylono Ustawę z dnia 29 marca $1962 \mathrm{r}$. o wyższych szkołach artystycznych; jednocześnie ustawą tą (z 1982 r.)

Komisja Kwalifikacyjna, zgodnie z art. 72 ust. 1 pkt 1, w brzmieniu nadanym Ustawą z dnia 31 III 1965 r. o zmianie ustawy o Polskiej Akademii Nauk (Dz.U. Nr 17, poz. 119). W sprawie regulaminu działania tych komisji i zakresu ich właściwości zob. Uchwała nr 166 Rady Ministrów z dnia 23 V 1960 r. w sprawie regulaminu Komisji Kwalifikacyjnej Pracowników Nauki (M.P. 1960 Nr 45, poz. 217) oraz Uchwała nr 210 Rady Ministrów z dnia 11 VIII 1965 r. w sprawie regulaminu Głównej Komisji Kwalifikacyjnej działającej przy Polskiej Akademii Nauk (M.P. Nr 44, poz. 250).

${ }^{41}$ Artykuł 19 pkt 2 i art. 19a Ustawy z dnia 12 IV 1973 r. o zmianie przepisów dotyczących stopni naukowych i tytułów naukowych oraz organizacji instytutów naukowo-badawczych (Dz.U. Nr 12, poz. 89). Zob. też dwie uchwały Rady Ministrów o jednobrzmiącym tytule - w sprawie wewnętrznej organizacji Centralnej Komisji Kwalifikacyjnej do Spraw Kadr Naukowych, zakresu działania jej organów oraz zasad wynagradzania stale urzędujących członków Komisji, wraz z załączonymi regulaminami tej Komisji, pierwsza - nr 106 z dnia 8 V 1973 r. (M.P. Nr 27, poz. 166), druga uchylająca tę uchwałę - nr 125 Rady Ministrów z dnia 15 VI 1976 r. (M.P. Nr 26, poz. 112). Zob. też Zarządzenie nr 4 Prezesa Rady Ministrów z dnia 19 II 1988 r. w sprawie organizacji i trybu działania Centralnej Komisji Kwalifikacyjnej do Spraw Kadr Naukowych, zakresu działania jej organów, a także zasad wynagradzania stale urzędujących członków Komisji (M.P. Nr 8, poz. 66).

42 Poza sprawami dotyczącymi nadawania tytułów profesora nadzwyczajnego i profesora zwyczajnego skierowanych do Centralnej Komisji przed dniem wejścia w życie ustawy z 1958 r. o szkołach wyższych i ich rozpatrzenia przez tę komisję na podstawie przepisów dotychczasowych (art. 150 ustawy z 1958 r. o szkołach wyższych). Na mocy art. 54 Ustawy z dnia 17 II 1960 r. o Polskiej Akademii Nauk działająca przy niej Komisja Kwalifikacyjna przejęła wszystkie funkcje Centralnej Komisji Kwalifikacyjnej do Spraw Pracowników Naukowych działającej na podstawie Ustawy z dnia 15 XII $1951 \mathrm{r}$. o szkołach wyższych i o pracownikach nauki (tekst jedn. Dz.U. 1956 Nr 45, poz. 205) w zakresie instytutów naukowych (naukowo-badawczych) istniejących poza Akademią i szkołami wyższymi.

${ }^{43}$ Artykuł 1 pkt 10 Ustawy z dnia 12 IV 1973 r. o zmianie przepisów dotyczących stopni naukowych i tytułów naukowych oraz organizacji instytutów naukowo-badawczych. 
ukonstytuowano na powrót instytucję Rady Wyższej Szkolnictwa Artystycznego oraz wprowadzono w odniesieniu do innych rodzajów szkolnictwa wyższego dwie kolejne rady: Radę Wyższego Szkolnictwa Medycznego oraz Radę Wyższego Szkolnictwa Kultury Fizycznej ${ }^{44}$. W roku 1985 przywrócono Centralną Komisję Kwalifikacyjną działającą przy prezesie Rady Ministrów i jej powierzono opiniowanie wniosków o nadanie tytułów naukowych ${ }^{45}$ (przy zachowaniu Rady Głównej Nauki i Szkolnictwa Wyższego z innym zakresem kompetencji), a ponadto do złożenia opinii o kandydacie do tytułu naukowego upoważniono Radę Wyższego Szkolnictwa Wojskowego lub Radę Wyższego Szkolnictwa Resortu Spraw Wewnętrznych odpowiednio w dziedzinie nauk wojskowych lub specjalistycznych dyscyplin naukowych o bezpieczeństwie państwa i porządku publicznym oraz ochronie przeciwpożarowej. I tego stanu rzeczy nie zmieniono do roku 1990.

W sytuacji (ścieżce) drugiej, sprowadzonej art. 18 ust. 4 ustawy z 1965 r. do uzasadnionych przypadków (bez ich podania), od powyższego trybu postępowania wprowadzono odstępstwo. Otóż minister sprawujący nadzór nad szkołą wyższą po zasięgnięciu opinii Rady Głównej Szkolnictwa Wyższego lub Sekretariat Naukowy PAN albo minister, któremu podlegał instytut naukowo-badawczy - mogli po zasięgnięciu opinii Głównej Komisji Kwalifikacyjnej działającej przy PAN szefowi rządu przedstawić wniosek o nadanie tytułu profesora zwyczajnego lub profesora nadzwyczajnego z pominięciem wniosku właściwej rady wydziału, rady naukowej, co oznaczało, po pierwsze, możliwość nadania tytułu profesora także osobie niezatrudnionej w szkole wyższej lub w placówce naukowej PAN, w instytucie naukowo-badawczym, po drugie, odstąpienie od zasięgania opinii Rady Głównej Szkolnictwa Artystycznego oraz Rady Wyższej Szkolnictwa Wojskowego w przypadkach przedstawienia kandydata do tytułu profesora odpowiednio w zakresie nauk artystycznych i wojskowych. Było to rozwiązanie podwójnie nietrafne, ponieważ: w uzasadnionych (niejasno) przypadkach pozwało wnioskować o nadanie tytułu profesora osobie niepoddanej postępowaniu o przedstawienie kandydata do tytułu profesora (tu miała wystarczyć jedynie opinia Rady Głównej Szkolnictwa Wyższego lub Sekretariatu Naukowego PAN albo ministra, któremu podlegał instytut naukowo-badawczy), a także dwie z pozostałych rad (Rada

\footnotetext{
${ }^{44}$ Artykuł 214 Ustawy z dnia 4 V 1982 r. o szkolnictwie wyższym.

${ }^{45}$ Zob. art. 1 pkt 16 Ustawy z dnia 25 VII 1985 r. o zmianie ustawy o stopniach naukowych i tytułach naukowych (Dz.U. Nr 36, poz. 168).
} 
Wyższego Szkolnictwa Artystycznego oraz Rada Szkolnictwa Wojskowego) pozbawiono prawa udziału w ocenie kandydata (w zakresie tych nauk), przedstawianego w uzasadnionych przypadkach szefowi rządu. Nie bez powodu obowiązek zasięgania opinii obu tych rad (Rady Wyższej Szkolnictwa Artystycznego oraz Rady Wyższego Szkolnictwa Wojskowego) wprowadzono w $1967 \mathrm{rr}^{46}$ na mocy art. 5 Ustawy z dnia 14 lutego $1967 \mathrm{r}$. o zmianie ustawy o wyższych szkołach artystycznych ${ }^{47}$. W roku 1973 wprawdzie art. 18 ust. 4 ustawy zachowano, jednak jego postanowienia nie sprowadzono już do uzasadnionych przypadków; rozszerzono także podmiotowy zakres nadzoru sprawowanego przez ministra nad szkołami wyższymi o samodzielne jednostki typu naukowo-dydaktycznego, a ponadto prawo zgłoszenia wniosku o nadanie tytułu profesora odtąd służyło nie tylko ministrowi, któremu podlegał dany instytut naukowo-badawczy, ale i temu, który nadzorował dany instytut albo jednostkę typu naukowo-badawczego (w 1985 r. od jednostek tych odstąipiono ${ }^{48}$ ).

Innego rodzaju odstępstwo wprowadzono przepisami przejściowymi ustawy z 1965 r. Otóż zgodnie z tą ustawą osobom niemającym stopnia naukowego docenta, a zajmującym w dniu jej wejścia w życie stanowiska docentów etatowych mogły być nadawane tytuły ustawą tą przewidziane, zaś osobom zajmującym stanowiska profesorów nadzwyczajnych - tytuły naukowe profesorów zwyczajnych (art. 23 ustawy). Od tego rozwiązania odstąpiono w $1968 \mathrm{r}^{49}$

Nadawanie tytułów naukowych (profesora nadzwyczajnego i profesora zwyczajnego), wzorem rozwiązań przyjętych ustawą z $1958 \mathrm{r}$. o szkołach wyższych, ustawa z 1965 r. o stopniach naukowych i tytułach naukowych pozostawiła Radzie Państwa, i były to także tytuły nadawane dożywotnio. Tym samym pozbawienie tytułu profesora mogło mieć miejsce wyłącznie w okolicznościach wyraźnie ustawą wskazanych, w razie: (1) skazania na karę więzienia za przestępstwo popełnione

\footnotetext{
${ }^{46}$ Zob. art. 18 ust. 4 Ustawy z dnia 31 III 1965 r. o stopniach naukowych i tytułach naukowych oraz art. 5 Ustawy z dnia 14 II 1967 r. o zmianie ustawy o wyższych szkołach artystycznych (Dz.U. Nr 6, poz. 20).

${ }^{47}$ Dz.U. Nr 6, poz. 20.

${ }^{48}$ Artykuł 1 pkt 15 Ustawy z dnia 25 VII 1985 r. o zmianie ustawy o stopniach naukowych i tytułach naukowych.

${ }^{49}$ Ustawą z dnia 20 XII 1968 r. o zmianie ustawy o stopniach naukowych i tytułach naukowych skreślono art. 23 Ustawy z dnia 31 III 1965 r. o stopniach naukowych i tytułach naukowych.
} 
z chęci zysku lub z innych niskich pobudek, (2) wymierzenia kary dyscyplinarnej wydalenia ze służby (najostrzejszej z kar dyscyplinarnych) przewidzianej w ustawie o szkolnictwie wyższym ${ }^{50}$, w ustawie o Polskiej Akademii Nauk ${ }^{51}$ i w ustawie o instytutach naukowo-badawczych ${ }^{52}$, a gdy chodzi o oficera zawodowego również (3) pozbawienia stopnia oficerskiego $\mathrm{w}$ trybie przewidzianym $\mathrm{w}$ przepisach o dyscyplinie wojskowej oraz o odpowiedzialności żołnierzy za przewinienia dyscyplinarne i za naruszenie honoru i godności żołnierskiej ${ }^{53}$. W tych przypadkach o pozbawieniu tytułu profesora orzekała Rada Państwa. Z mocy prawa pozbawienie tytułu profesora następowało $\mathrm{w}$ razie skazania na utratę praw publicznych lub obywatelskich praw honorowych, a w odniesieniu do oficera także w razie jego skazania na karę degradacji.

Bez wątpienia, przyjęty ówcześnie tryb postępowania w przedmiocie nadania tytułu profesora (nadzwyczajnego i zwyczajnego) był scentralizowany i w żadnym razie przez ustanowienie różnych rad czy komisji (Głównej bądź Wyższej) nie uzasadniał przyjęcia oceny przeciwnej. Stanowiska tego nie łagodziły, wbrew założeniom ustawodawcy, postanowienia ustawy z 1965 r. dopuszczające, w uzasadnionych przypadkach, możliwość odstąpienia przez ministra sprawującego nadzór nad szkołą wyższą (po zasięgnięciu opinii Rady Głównej Szkolnictwa Wyższego) lub Sekretariatu Naukowego PAN albo ministra, któremu podlegał instytut naukowo-badawczy (po zasięgnięciu opinii Głównej Komisji Kwalifikacyjnej działającej przy PAN), od obowiązku zachowania trybu przedstawienia szefowi rządu kandydata do tytułu naukowego na zasadach określonych art. 18 ust. 2 ustawy (w postępowaniach standardowych). Przyjęcie art. 18 ust. 4 ustawy tak dalece uproszczonego rozwiązania nabiera szczególnego znaczenia, jeśli się je odniesie do możliwości nadania tytułu naukowego profesora nadzwyczajnego lub profesora zwyczajnego, w wyjątkowych przypadkach, osobie niemającej stopnia naukowego i tytułu naukowego.

\footnotetext{
${ }^{50}$ Artykuł 115 pkt 5 Ustawy z dnia 5 XI 1958 r. o szkołach wyższych; art. 196 ust. 1 pkt 5 (zwolnienie z pracy) Ustawy z dnia 4 V 1982 r. o szkolnictwie wyższym.

${ }^{51}$ Artykuł 53 ust. 2 pkt 4 Ustawy dnia 17 II 1960 r. o Polskiej Akademii Nauk (tekst jedn. Dz.U. 1965 Nr 17, poz. 119).

${ }^{52}$ Artykuł 34 ust. 2 pkt 5 Ustawy z dnia 17 II 1961 r. o instytutach naukowo-badawczych (tekst jedn. Dz.U. 1965 Nr 19, poz. 129).

${ }^{53}$ Zob. art. 13, art. 22 ust. 3 pkt 2 Ustawy z dnia 21 V 1963 r. o dyscyplinie wojskowej oraz o odpowiedzialności żołnierzy za przewinienia dyscyplinarne i za naruszenia honoru i godności żołnierskiej (Dz.U. Nr 22, poz. 114).
} 


\section{Podsumowanie}

Wyłączenie z początkiem 1965 r. z prawa szkół wyższych prawnej regulacji w zakresie nadawania tytułów naukowych (profesora nadzwyczajnego lub profesora zwyczajnego), bez wątpienia, było na ówczesne czasy aktem znaczącym. Nie od razu wprawdzie prowadziło ono do pełnego zerwania z dotychczasowa prawem uregulowaną i tradycyjnie przyjętą formułą rozwiązań odnośnie do postępowań w przedmiocie nadania tytułu naukowego, niemniej dawało wyraz potrzebie poczynienia znaczących zmian w tym zakresie.

Proces ówcześnie przyjętych przemian był wielowarstwowy i z reguły poddany $\mathrm{w}$ różnym stopniu zmianom. Przy zawężeniu prawa do nadawania jedynie dwóch tytułów naukowych (profesora nadzwyczajnego, profesora zwyczajnego) zmianami objęto tryb i warunki wszczęcia postępowania w sprawie wysunięcia kandydata do tytułu profesora, warunki wymagane od kandydata do tytułu naukowego, warunki i tryb postępowania organów współuczestniczących w procesie prowadzącym do nadania każdego z tych tytułów naukowych. Ponieważ nie był to okres stabilnych rozwiązań prawnych, nie dziwi, że przyjęte przed 1965 r. rozwiązania nie tylko były nacechowane ideologią komunistycznych wartości, ale też w znacznie większym stopniu podporządkowano je ówcześnie stawianym oczekiwaniom państwa socjalistycznego. Po roku 1965 wprawdzie nie od razu wydźwięk ideologicznych założeń zelżał, jednak znacznie wyraźniejsze stało się uporządkowanie i uproszczenie rozwiązań wcześniej przyjętych w tym zakresie. Nie oznacza to, że nadawanie tytułów profesora oderwano od wartości ideologicznych ówczesnej Polskiej Rzeczypospolitej Ludowej, wyraźnie już ustawą zdefiniowanych w 1985 r.

Nie bez uzasadnienia przyjęte ustawą z 1965 r. rozwiązania wyznaczały dwie drogi prowadzące do wszczęcia postępowania w sprawie wysunięcia wniosku o nadanie tytułu naukowego profesora kandydatom posiadającym stopień naukowy lub stopnia tego niemających, zatrudnionych w szkołach wyższych, placówkach naukowych PAN lub instytutach naukowo-badawczych, jak i zatrudnionym poza nimi, przy przyjęciu zarazem skróconego trybu postępowania w tym przedmiocie, podyktowanego uzasadnionymi przypadkami.

Te ze zmian, które bez wątpienia były ważne i nowe, sprowadzały się do bliższego określenia dziedzin nauki, w których tytuły naukowe profesora mogły być nadawane, a także do stopniowego uproszczania postępowania prowadzącego do wysunięcia przez właściwą radę (wydziałową, 
naukową) wniosku w sprawie kandydata do jednego z dwóch tytułów profesora (nadzwyczajnego lub zwyczajnego). Od 1968 r. po raz pierwszy (poczynając od rozwiązań z 1920 r.) odstąpiono w szkołach wyższych od praktyki zasięgania opinii o kandydacie w gronie profesorów innych uczelni na rzecz zwiększenia z dwóch do trzech liczby recenzentów oceniających dorobek naukowy i osiągnięcia kandydata w zakresie opieki nad młodą kadrą naukową. Dorobek naukowy wraz z wynikami w kształceniu kadry naukowej przez kandydata podlegał jednakże ustawowym zmianom (od wybitnych do poważnych jego osiągnięć w zakresie obu poddawanych ocenie warunków). Różnicę w pojmowaniu tych pojęć pozostawiono recenzentom, a ponadto - przy braku ustawowego zdefiniowania przesłanki osiągnięć w kształceniu kadry naukowej - swobodną ocenę także tej przesłanki. Znacznie wyraźniej zdefiniowano pozycję i rolę Sekretariatu Naukowego PAN oraz kierowników (dyrektorów) instytutów naukowo-badawczych w tym zakresie.

Innej ocenie podlegają natomiast zmiany rozwiązań prawnych dotyczące naczelnych organów administracji państwowej współuczestniczących w postępowaniu o nadanie tytułu profesora. Wprawdzie do końca okresu objętego badaniem zachowano uprawnienie szefa rządu do złożenia wniosku o nadanie tytułów profesora oraz prawo Rady Państwa do ich nadawania (także pozbawienia w sytuacjach przewidzianych prawem), jednak zmiany wprowadzone w tym zakresie miały szerszy zasięg. Przede wszystkim dowodziły niestabilności regulacji kształtujących udział Rady Głównej Szkolnictwa Wyższego oraz Centralnej Komisji Kwalifikacyjnej i innych rad szkolnictwa wyższego opiniujących wnioski właściwych rad (wydziału, naukowej) przed ich przedstawieniem prezesowi Rady Ministrów, a także udział tych ostatnich rad w przedstawianiu swoich opinii ministrom właściwym w zakresie określonych nauk.

\section{THE TITLE OF PROFESSOR IN POLAND IN THE YEARS 1920-1990. PART 2. CONDITIONS FOR AWARDING THE TITLE OF PROFESSOR UNDER THE LAW ON DEGREES AND ACADEMIC TITLES}

\section{S u m mary}

The issues concerning the conferment of the title of Professor regulated by the law on academic degrees and academic titles covered a period of twenty-five years. This is much shorter than subjecting proceedings in this area to the law on higher 
education for the past forty-five years. It is not without reason that during the seventy years (1920-1990) covered by both parts of the study issues related to the conferring the title of professor were subject to significant changes, in accordance with the changing legal and factual reality of the People's Republic, the Polish People's Republic, and the Republic of Poland.

The 1965 Act on Academic Degrees and Scientific Titles undoubtedly differed from the legislation in force in the People's Republic and in the first years of the Polish People's Republic. Its unquestioned advantage was: (1) a limited number of academic titles of professor, restricted to extraordinary and ordinary professor, (2) identified fields of science in which these titles could be awarded, and (3) a gradual simplification of the procedure for applying for the award of the academic title to a candidate in universities, scientific institutions of the Polish Academy of Sciences and research institutes. Although in this respect, the provisions of the Act of 1965 together with the secondary legislation issued on its basis were subject to amendments, as a rule they were limited to clarifying the legal solutions adopted earlier, or to increasing the requirements imposed on candidates for the title of professor, except for candidates not possessing a degree or a scientific title, subject to a separate legal regime dictated by exceptional cases.

The wider scope of changes concerned the procedure for presenting to the Prime Minister by competent ministers and the Scientific Secretariat of the Polish Academy of Sciences (PAN) candidates for the academic title and the requirements related to the obligation put on these bodies to seek the opinion of the General Council for Higher Education, the Central Qualification Commission, or competent Higher Education Councils in the scope of a relevant science.

Keywords: titles of extraordinary professor and ordinary professor between 1965 and 1990 - universities - scientific institutions of the Polish Academy of Sciences and scientific and research institutes - procedure for awarding the title of professor 